УДК 378.09:004.42.056]:81'243](477)(045)

DOI: https://doi.org/10.35387/od.1(19).2021.141-149

Ящук Ольга Вікторівна аспірантка кафредри психології, педагогіки і туризму Київського національного лінгвістичного університету
Yashchuk Olga - PhD Student of the Department of Psychology, Pedagogy and Tourism, Kyiv National Linguistic University

ORCID iD: https://orcid.org/0000-0003-2991-0801

E-mail: olga.yashchuk.ua@gmail.com

\title{
ОСВІТНЬО-НОРМАТИВНЕ ЗАБЕЗПЕЧЕННЯ ІНШОМОВНОЇ ПІДГОТОВКИ МАЙБУТНІХ ФАХІВЦІВ ІЗ КІБЕРБЕЗПЕКИ В УКРАЇНІ: КОМПЕТЕНТНІСНИЙ ВИМІР
}

Анотація. Оглядова стаття грунтується на вивченні теоретичних передумов іншомовної підготовки майбутніх фрахівців із кібербезпеки. У наш час кібербезпека як сукупність профессійних дій $i$ заходів щодо програмного, технічного захисту стає дедалі затребуванішим напрямом діяльності, що актуалізує питання про шляхи вдосконалення профресійної підготовки здобувачів, майбутніх фрахівців у цій галузі в технічних університетах. Одним із суттєвих показників відповідності фраховим вимогам і виявом професійної компетентності $\epsilon$ рівень сфрормованості іншомовного комунікативного потенціалу здобувачів. Зокрема, це зумовлено необхідністю активної комунікації для збагачення власного професійного, практичного досвіду інноваційними, прогресивними напрацюваннями іноземних спеціалістів. Теоретичне підгрунтя професійного вишколу становлять грамотно розроблені нормативні документи, що регулюють зміст підготовки. У статті проаналізовано базове освітньо-нормативне забезпечення й окреслено передумови, які визначають алгоритм іншомовної підготовки майбутніх фрахівців і визначають рівень їі результативності. З'ясовано, що опорні точки іншомовної підготовки фокусуються в компетентнісній парадигмі профрілів нормативних документів. Наголошено на необхідності розвитку іншомовної комунікативної компетентності здобувачів у контексті збалансованого співвідношення загальної іноземної мови й іноземної профресійного спрямування. Схарактеризовано основні суперечності, усунення яких уможливлює покращення якості іншомовної підготовки фрахівців. Спрогнозовано подальший напрям наукового дослідження в порівняльному контексті діяльності британських університетів, що здійснюють підготовку інженерів із кібербезпеки.

Ключові слова: кібербезпека; фрахівець із кібербезпеки; компетентність; іншомовна підготовка. 


\title{
Yashchuk Olga
}

\section{EDUCATIONAL AND REGULATORY PROVISION OF FOREIGN LANGUAGE TRAINING OF FUTURE CYBERSECURITY SPECIALISTS IN UKRAINE: THE COMPETENCE DIMENSION}

\begin{abstract}
The article highlights the theoretical prerequisites of foreign language training of future cybersecurity professionals. Cybersecurity as a practice of protecting systems, networks, data is becoming a highly demanded area of activity. This poses the question of advanced training of specialists in the field in technical universities. One of the essential indicators of compliance with professional requirements and manifestation of professional competence is the appropriate level of foreign language communicative proficiency of applicants. The article is based on clarification of the preconditions that create the frame for implementation of educational actions in foreign language training of future cybersecurity professionals. We have analyzed the educational and regulatory documents outlining the algorithm for training such specialists in Ukrainian educational institutions. It has been ascertained that the reference points for forming a trajectory of foreign language training focus in the competence paradigm of normative documents' profiles. In this context, it is emphasized on the necessity to find the ways to developing foreign language communicative competence of applicants for both the professional fulfilment and meeting the personal needs of applicants. From the perspective of educational experience analysis the main contradictions have been characterized, elimination of which makes it possible to significantly improve foreign language training of cyber defenders. Given the respectability and reputability of British educational institutions it has been determined that our further scientific research lies in the comparative plane of cybersecurity engineers training experience of technical universities in Great Britain.
\end{abstract}

Key words: cybersecurity; cybersecurity specialist; competence; foreign language training.

Постановка проблеми, їі актуальність. На сучасному етапі науково-технічного прогресу виокремилося нове явище, що $є$ наслідком виходу на наступний цикл технологічного розвитку суспільства цифровізація як шлях трансформації інфрормаційного контенту в електронній, віртуальній площині. У такому фрорматі порушуються проблеми щодо налагодження професійного захисту діяльності, пов'язаної з накопиченням, поширенням, використанням інформації у віртуальному вимірі, що потребує залучення спеціально підготовлених і обізнаних фрахівців у сфрері захисту об'єктів і суб'єктів віртуального інформаційного середовища. Забезпечення потужного сегменту ринку праці професіоналами з кібербезпеки - пріоритетне завдання державної політики в багатьох країнах, і запорукою його вирішення $€$ оптимізація навчально-професійної підготовки майбутніх фахівців, зокрема, крізь призму вдосконалення іншомовної підготовки. 
Аналіз останніх досліджень і публікацій. 3 позицій методики з'ясовано, що «те, як використовується мова в професійному середовищі, істотно не відрізняється від спеціальності до спеціальності» (Програма 3 англійської мови..., 2005, с. 13). Напрацювання вчених щодо особливостей іншомовної підготовки у вищій школі відображені в наукових розвідках Т. Коваль і О. Матвієнко (схарактеризували тенденції мовної підготовки майбутніх фахівців у контексті впливу інформаційно-комунікаційних технологій) (2012), О. Синекоп (вивчала особливості імплементації міждисциплінарного підходу в навчання іноземних мов фахівців) (2015), О. Нітенко (дослідила особливості іншомовної підготовки фрахівців у порівняльному контексті європейського досвіду) (2015), О. Ванівської (схарактеризувала сутнісні аспекти компетентнісного підходу щодо викладання/навчання іноземних мов у вищій школі) (2016). Водночас, виокремлюючи актуальність й сучасність фаху кіберзахисника й іншомовну підготовку як значущу частину професійної підготовки таких фахівців, маємо констатувати відсутність комплексних, ґрунтовних джерел, які б у зазначеному контексті засвідчували наявність конкретних результатів здійснених наукових пошуків.

Мета статті полягає у вивченні опорних точок в основних освітньонормативних документах як базису, до якого «прив'язані» необхідні, передусім, компетентнісні вектори, що фрормують підґрунтя відповідної методології навчання іноземних мов майбутніх фахівців із кібербезпеки.

Виклад основного матеріалу дослідження. Одностайність думок освітян і науковців щодо актуальності проблематики іншомовної підготовки підтверджується тезою про те, що «зважаючи на інтеграційні процеси та розширення міжнародних зв'язків, володіння іноземними мовами стало однім із суттєвих показників фаховості, компетентності, перетворилося на вирізнювальну кваліфікаційну ознаку» (Гаманюк \& Амеліна, 2014, с. 239). Аналізуючи європейський педагогічний досвід, О. Нітенко зазначає, що зміст іншомовної підготовки полягає «в системному оволодінні іноземними мовами на основі міждисциплінарної інтеграції 3 урахуванням індивідуальних якостей особистості, спрямованому на досягнення такого рівня професійної іншомовної комунікативної компетентності, що забезпечить міжкультурне та міжособистісне спілкування для вирішення професійних завдань у полікультурному, мультилінгвальному глобалізованому суспільстві» (Нітенко, 2015, с. 58). Таким чином, переосмислення освіти як рушійного чинника розвитку суспільства супроводжується трансформацією «освіти для знань» в «освіту для вмінь і компетентностей». Утілення компетентнісної парадигми стає частиною філософії сучасної особистісно центрованої освіти. У загальних положеннях першого розділу Закону України «Про вищу освіту» (ст. 1, п. 13), зазначено, що «компетентність здатність особи успішно соціалізуватися, навчатися, провадити професійну діяльність, яка виникає на основі динамічної комбінації знань, умінь, навичок, способів мислення, поглядів, цінностей, інших особистих якостей» (2014). Сутність компетентностей відповідно до розмежування в 
стандартах вищої освіти полягає в тому, що інтегральна компетентність $€$ узагальненим описом кваліфікаційного рівня, який виражає основні компетентнісні характеристики рівня щодо навчання та/або професійної діяльності; загальні (універсальні) компетентності не залежать від предметної області, але важливі для успішної подальшої професійної та соціальної діяльності здобувача в різних галузях та для його особистісного розвитку; спеціальні (фахові, предметні) компетентності залежать від предметної області та є важливими для успішної професійної діяльності за певною спеціальністю (Методичні рекомендації..., 2017). Прикметним є той факт, що в переліку проєкту Тьюнінг першою загальною компетентністю прописано «здатність спілкуватися другою (іноземною) мовою» (Методичні рекомендації..., 2016, с. 49).

У затвердженому стандарті вищої освіти за спеціальністю 125 «Кібербезпека» галузі знань 12 «Інформаційні технології» для першого (бакалаврського) рівня вищої освіти 3-поміж загальних компетентностей виокремлено «здатність професійно спілкуватися державною та іноземною мовами як усно, так і письмово», а результати навчання передбачають «застосовування знань державної та іноземних мов з метою забезпечення ефективності професійної комунікації» (Стандарт вищої освіти..., 2018). У нормативному змісті затвердженого стандарту вищої освіти за спеціальністю 125 «Кібербезпека» галузі знань 12 «Інформаційні технології» другого (магістерського) рівня вищої освіти 3-поміж очікуваних результатів підготовки здобувачів виділено вміння «вільно спілкуватись державною та іноземною мовами, усно і письмово для представлення і обговорення результатів досліджень та інновацій, забезпечення бізнес/операційних процесів та питань професійної діяльності в галузі інформаційної безпеки та/або кібербезпеки» (Стандарт вищої освіти..., 2021).

Зазначені положення стандартів ураховано в освітньопрофесійних програмах фракультетів технічних університетів, що готують фахівців із кібербезпеки. Так, у профілях програм зі спеціальності 125 «Кібербезпека» за спеціалізацією «Системи, технології та математичні методи кібербезпеки» для кваліфікації «бакалавр» i «магістр» (Національний технічний університет Украіни «Київський політехнічний інститут імені Ігоря Сікорського», Фізико-технічний інститут) у переліку загальних компетентностей прописана «ЗК 3 здатність професійно спілкуватися державною та іноземною мовами як усно, так і письмово» (Освітньо-професійна програма...другого (магістерського) рівня, 2020; Освітньо-професійна програма... першого (бакалаврського) рівня, 2020). У цьому контексті сформульовано мету навчальних дисциплін «Практичний курс іноземної мови для професійного спілкування II» і «Практичний курс іноземної мови для наукового спілкування І» для підготовки бакалаврів і здобувачів ступеня магістра за спеціальністю 125 «Кібербезпека», що передбачає «формування у студентів професійно орієнтованої лінгвосоціокультурної компетентності на вищезазначеному рівні; формування у студентів професійно орієнтованих мовних 
компетентностей; формування у студентів професійно орієнтованої навчально-стратегічної компетентності» й «одержання необхідного рівня сформованості професійно орієнтованої іншомовної комунікативної компетентності» (Практичний курс іноземної мови..., 2020; Програма 3 англійської мови..., 2005).

Той факт, що іншомовно-комунікативний компетентнісний складник вбудовано в ланки здатностей здобувача, майбутнього фахівця в згаданих базових документах, свідчить про значущість іншомовного мовленнєвого аспекту в процесі професійної підготовки. Ми поділяємо думку про те, що «мовленнєві вміння визначаються й інтегруються відповідно до мовної поведінки, яка $є$ специфічною для сфер і ситуацій, пов'язаних із навчанням та спеціалізацією» (Програма 3 англійської мови..., 2005, с. 7). Разом із тим, більшість українських викладачів, що навчають іноземних мов студентів інженерно-технічних спеціальностей, надто буквально асоціюють іноземну мову професійного спрямування (що перетинається з призначеністю поширеного й активно використовуваного підходу в зарубіжному досвіді - англійської (іноземної) мови для спеціальних цілей) з фаховим дискурсом і «цільовими», «спеціальнісними» настановами. Насправді можливості «іноземної мови для спеціальних цілей» виходять за рамки усталеної у вітчизняній практиці навчання традиції вивчати вузькогалузеву термінологію й опрацьовувати «фахові» тексти й можуть ефективно реалізуватися в компетентнісному й діяльнісному вимірі. Тому крізь призму зазначених чинників констатуємо необхідність ретельного продумування шляхів іншомовної підготовки майбутніх фахівців із кібербезпеки, базисом якої $€$ збалансоване співвідношення навчання загальної іноземної мови, іноземної мови для спеціальних цілей, а також грамотна синхронізація компетентнісного, діяльнісного й міждисциплінарного підходів до навчання.

Висновки і перспективи подальших досліджень. Досягнення належного рівня мовної освіченості фахівця передбачає збалансований взаємозв'язок відповідних навчальних заходів, розроблення програм, методів, комунікативних стратегій, які використовуються в процесі здійснення навчальної підготовки в закладах вищої освіти. Іншомовна підготовка є невід'ємним чинником якості професійного вишколу майбутніх кіберзахисників, а тому означені в статті аспекти потребують переосмислення підходів у комплексній парадигмі навчання іноземних мов фахівців, починаючи з її наповнення актуальним компетентнісним змістом. Компетентнісний чинник, зумовлений усуненням «архаїчних» шаблонів викладання/навчання іноземної мови, а також гармонізацією співвідношення «іноземної мови для спеціальних цілей» і «загальної іноземної мови», значно розгортає простір для використання набутих знань, умінь і навичок з іноземної мови в подальшій професійній діяльності й особистісній сфрері.

Усеохопність контексту нашого наукового пошуку потребує опертя на європейський професійно-педагогічний досвід, зокрема, авторитетних і репутабельних технічних університетів (інженерних шкіл) Великої Британії, 
де впродовж століть сформовано взірцеві освітні традиції й забезпечується фундаментальність та якість підготовки фахівців. Тож наступний етап наукової розвідки передбачає порівняльний аналіз освітньо-нормативної бази, що регулює алгоритм іншомовної підготовки інженерів із кібербезпеки у британських закладах вищої освіти.

\section{Список використаних джерел}

Ванівська, О.М. (2016). Реалізація компетентнісного підходу в процесі викладання іноземної мови у вищій школі. Науковий вісник ужгородського університету, 1 (38), 71-75.

Вступне слово до проекту ТЬЮНІНГ - гармонізація освітніх структур у Європі. Внесок університетів у Болонський процес. (2006). URL: https://www.unideusto.org/tuningeu/images/stories/documents/General Brochure_Ukrainian_version.pdf

Гаманюк, В.А. \& Амеліна, С.М. (2014). Стандартизація іншомовної підготовки в контексті інтеграції до загальноєвропейського освітнього простору. Педагогіка вищої та середної школи, 42, 234-244.

Загальноєвропейські Рекомендації з мовної освіти: вивчення, викладання, оцінювання. (2003). Наук. ред. С.Ю. Ніколаєва. Київ: Ленвіт.

Коваль, Т.І. \& Матвієнко, О.В. (2012). Сучасні напрями мовної підготовки майбутніх фахівців в умовах впровадження інформаційнокомунікаційних технологій у вищій школі. Інформаційнотелекомунікаційні технології в сучасній освіті: досвід, проблеми, перспективи: III Міжнар. наук. -практ. конф. ЛДУБЖД, 256-261.

Методичні рекомендації для розроблення профрілів ступеневих програм, включаючи програмні компетентності та програмні результати навчання. (2016). Пер. з англ. Ю. Рашкевич. Київ: ТОВ «Поліграф плюс».

Методичні рекомендації щодо розроблення стандартів вищої освіти: затв. Наказом Міністерства освіти і науки України від «01» червня 2017 р. № 600 (у редакції наказу МОН України від 21 грудня 2017 p. № 1648). URL: https://mon.gov.ua/storage/app/media/vishchaosvita/proekty\%20standartiv\%20vishcha\%20osvita/1648.pdf

Нітенко, О.В. (2015). Іншомовна підготовка фрахівців права в трицикловій системі вищої освіти: європейський досвід: дис. ... д-ра пед. наук: 13.00.04. Київ: ІВО НАПН України.

Практичний курс іноземної мови для наукового спілкування I (2020). Робоча програма кредитного модуля для підготовки здобувачів ступеня магістра за спеціальністю 113 «Прикладна математика», 125 «Кібербезпека», 105 «Прикладна фрізика та наноматеріали». Уклад. Д. С. Приходько. Київ: КПІ ім. Ігоря Сікорського. URL: https://kamts2.kpi.ua/node/418

Практичний курс іноземної мови для професійного спілкування II. (2020). Робоча програма кредитного модуля для підготовки бакалаврів за спеціальністю 113 «Прикладна математика», 125 
«Кібербезпека». Уклад. Д.С. Приходько. Київ: КПІ ім. Ігоря Сікорського. URL: https://kamts2.kpi.ua/node/418

Про вищу освіту. Закон України № 1556-VII від 1.07.2014. URL: https://zakon.rada.gov.ua/laws/show/1556-18\#Text

Програма з англійської мови для профресійного спілкування. (2005). Київ: Ленвіт.

Синекоп, О.С. (2015). Особистісний компонент в особистісно-діяльнісному підході навчання англійської мови студентів технічних спеціальностей засобами міждисциплінарних зв'язків. Педагогічні науки, 126, 132-138.

Системи, технології та математичні методи кібербезпеки (2020). Освітньопрофресійна програма другого (магістерського) рівня за спеціальністю 125 «Кібербезпека» галузі знань 12 «/нформаційні технологї̈». Київ: КПI ім. Ігоря Сікорського. URL: https://drive.google.com/file/d/16EkuksXYQ19SeL5nobth6xRIY_6kRcl/view

Системи, технології та математичні методи кібербезпеки. (2020). Освітньопрофресійна програма першого (бакалаврського) рівня за спеціальністю 125 «Кібербезпека» галузі знань 12 «Інформаційні технології». Київ: КПI ім. Ігоря Сікорського. URL: https://drive.google.com/file/d/1O6hImxhQdZZISgGalBmUbNemKyXIk 2ca/view

Стандарт вищої освіти України за спеціальністю «Кібербезпека» галузі знань 12 «Інформаційні технології» для другого (магістерського) рівня вищої освіти. (2021). Київ: MOH. URL: https://mon.gov.ua/ua/osvita/visha-osvita/naukovo-metodichna-radaministerstva-osviti-i-nauki-ukrayini/zatverdzheni-standarti-vishoyi-osviti

Стандарт вищої освіти України за спеціальністю «Кібербезпека» галузі знань 12 «Інфрормаційні технології» для першого (бакалаврського) рівня вищої освіти. (2018). Київ: МОН України. URL: $\quad$ https://mon.gov.ua/storage/app/media/vishchaosvita/zatverdzeni\%20standarty/12/21/125-kierbezpeka-bakalavr.pdf

\section{References (translated and transliterated)}

Vanivska, O.M. (2016). Realizatsiia kompetentnisnoho pidkhodu $v$ protsesi vykladannia inozemnoi movy u vyshchii shkoli [Implementation of the competence approach in the process of teaching a foreign language in higher school]. Naukovyi visnyk uzhhorodskoho universytetu, 1 (38), 71-75 [in Ukrainian].

Vstupne slovo do proektu TIUNINH - harmonizatsiia osvitnikh struktur u Yevropi. Vnesok universytetiv u Bolonskyi protses [The introductory word to the TUNING project - harmonization of educational structures in Europe. The contribution of universities to the Bologna Process]. (2006). URL: https://www.unideusto.org/tuningeu/images/stories/documents/General_Br ochure_Ukrainian_version.pdf [in Ukrainian]. 
Hamaniuk, V.A. \& Amelina, S.M. (2014). Standartyzatsiia inshomovnoi pidhotovky v konteksti intehratsii do zahalnoievropeiskoho osvitnoho prostoru [Standardization of foreign language training in the context of integration into the European educational space]. Pedahohika vyshchoi ta serednoi shkoly - Higher and secondary school pedagogy, 42, 234-244 [in Ukrainian].

Zahalnoievropeiski Rekomendatsii z movnoi osvity: vyvchennia, vykladannia, otsiniuvannia [Common European Recommendations for language education: study, teaching, assessment]. (2003). Nauk. red. S.Yu. Nikolaieva. Kyiv: Lenvit [in Ukrainian].

Koval, T.I. \& Matviienko, O.V. (2012). Suchasni napriamy movnoi pidhotovky maibutnikh fakhivtsiv $v$ umovakh vprovadzhennia informatsiinokomunikatsiinykh tekhnolohii u vyshchii shkoli [Modern trends of language training of future specialists in the conditions of introduction of information and communication technologies in higher school]. Informatsiinotelekomunikatsiini tekhnolohii $v$ suchasnii osviti: dosvid, problemy, perspektyvy: III Mizhnar. nauk.-prakt. konf. LDUBZhD, 256-261 [in Ukrainian].

Metodychni rekomendatsii dlia rozroblennia profiliv stupenevykh prohram, vkliuchaiuchy prohramni kompetentnosti ta prohramni rezultaty navchannia [Guidelines for developing profiles of degree programs, including program competencies and program learning outcomes]. (2016). Per. z anhl. Yu. Rashkevych. Kyiv: TOV «Polihraf plius» [in Ukrainian].

Metodychni rekomendatsii shchodo rozroblennia standartiv vyshchoi osvity [Methodical recommendations for the development of higher education standards]: zatv. Nakazom MON Ukrainy vid «01» chervnia 2017 № 600 (u redaktsii nakazu Ministerstva osvity i nauky Ukrainy vid 21 hrudnia 2017 № 1648). URL: https://mon.gov.ua/storage/app/media/vishchaosvita/proekty\%20standartiv\%20vishcha\%20osvita/1648.pdf [in Ukrainian].

Nitenko, O.V. (2015). Inshomovna pidhotovka fakhivtsiv prava $v$ trytsyklovii systemi vyshchoi osvity: yevropeiskyi dosvid [Foreign language training of legal professionals in the tricycle system of higher education: European experience]. DSc thesis. Kyiv [in Ukrainian].

Praktychnyi kurs inozemnoi movy dlia naukovoho spilkuvannia I [Practical foreign language course for scientific communication I]. (2020). Robocha prohrama kredytnoho modulia dlia pidhotovky zdobuvachiv stupenia mahistra za spetsialnistiu 113 "Prykladna matematyka», 125 "Kiberbezpeka», 105 "Prykladna fizyka ta nanomaterialy» [Work program of the credit module for preparation of masters on the specialty 113 «Applied mathematics», 125 «Cybersecurity», 105 «Applied physics and nanomaterials»]. Uklad. D.S. Prykhodko. Kyiv: KPI im. Ihoria Sikorskoho. URL: https://kamts2.kpi.ua/node/418 [in Ukrainian].

Praktychnyi kurs inozemnoi movy dlia profesiinoho spilkuvannia II [Practical foreign language course for professional communication II]. (2020). Robocha prohrama kredytnoho modulia dlia pidhotovky bakalavriv za spetsialnistiu 113 "Prykladna matematyka», 125 "Kiberbezpeka» [Work program of the credit module for preparation of bachelors on the specialty 113 «Applied mathematics», 125 «Cyber security»]. Uklad. D.S. Prykhodko. Kyiv: KPI im. Ihoria Sikorskoho. URL: https: //kamts2.kpi.ua/node/418 [in Ukrainian]. 
Pro vyshchu osvitu. Zakon Ukrainy [About higher education [The Law of Ukraine] № 1556-VII vid 1.07.2014. URL: https://zakon.rada.gov.ua/laws/show/1556-18\#Text [in Ukrainian].

Prohrama $z$ anhliiskoi movy dlia profesiinoho spilkuvannia [English language program for professional communication]. (2005). Kyiv: Lenvit [in Ukrainian].

Synekop, O.S. (2015). Osobystisnyi komponent v osobystisno-diialnisnomu pidkhodi navchannia anhliiskoi movy studentiv tekhnichnykh spetsialnostei zasobamy mizhdystsyplinarnykh zviazkiv [Personal component in the personal-activity approach of teaching English to students of technical specialties by means of interdisciplinary links]. Pedahohichni nauky Pedagogical sciences, 126, 132-138 [in Ukrainian].

Systemy, tekhnolohii ta matematychni metody kiberbezpeky [Systems, technologies and mathematical methods of cybersecurity]. (2020). Osvitno-profesiina prohrama druhoho (mahisterskoho) rivnia za spetsialnistiu 125 "Kiberbezpeka» haluzi znan 12 «Informatsiini tekhnolohii» [Educational and professional program of the second (master's) level in the specialty 125 "Cybersecurity» in the field of knowledge 12 «Information Technology»]. Kyiv: KPI im. Ihoria Sikorskoho. URL: https://drive.google.com/file/d/16EkuksXYQ19-

SeL5nobth6xRIY_6kRcl/view [in Ukrainian].

Systemy, tekhnolohii ta matematychni metody kiberbezpeky [Systems, technologies and mathematical methods of cybersecurity]. (2020). Osvitno-profesiina prohrama pershoho (bakalavrskoho) rivnia za spetsialnistiu 125 "Kiberbezpeka» haluzi znan 12 «Informatsiini tekhnolohii» [Educational and professional program of the first (bachelor's) level in the specialty 125 "Cybersecurity» in the field of knowledge 12 "Information Technology»]. Kyiv: KPI im. Ihoria Sikorskoho. URL: http://surl.li/yvnv [in Ukrainian].

Standart vyshchoi osvity Ukrainy za spetsialnictiu «Kiberbezpeka» haluzi znan 12 «Informatsiini tekhnolohii» dlia druhoho (mahisterskoho) rivnia vyshchoi osvity [The standard of higher education of Ukraine in the specialty «Cybersecurity» in the field of knowledge 12 «Information technology» for the second (master's) level of higher education]. (2021). Kyiv: MON Ukrainy. URL: https://mon.gov.ua/ua/osvita/visha-osvita/naukovometodichna-rada-ministerstva-osviti-i-nauki-ukrayini/zatverdzheni-standartivishoyi-osviti [in Ukrainian].

Standart vyshchoi osvity Ukrainy za spetsialnictiu «Kiberbezpeka» haluzi znan 12 «Informatsiini tekhnolohii» dlia pershoho (bakalavrskoho) rivnia vyshchoi osvity [The standard of higher education of Ukraine in the specialty «Cybersecurity» in the field of knowledge 12 «Information technology» for the first (bachelor's) level of higher education]. (2018). Kyiv: MON Ukrainy. URL: https://mon.gov.ua/storage/app/media/vishcha-osvita/zatverdzeni\% 20standarty/12/21/125-kierbezpeka-bakalavr.pdf [in Ukrainian]. 